\title{
Relationship between functional movement screening and static balance scores: Increasing the educational level of elite female wrestlers
}

\section{Relación entre la detección del movimiento funcional y las puntuaciones de equilibrio estático: aumento del nivel educativo de las luchadoras de élite}

Erhan Kara*
Tekirdağ Namık Kemal University, School of Physical Education and Sport Department, Tekirdağ, Turkey

\section{Sercan Öncen}

Tekirdağ Namık Kemal University, School of Physical Education and Sport Department, Tekirdağ, Turkey

Ísa Sağıroğlu

Associate Professor Trakya University Kirkpınar Faculty of Sports Science, Edirne, Turkey

\section{Özgür Dinçer}

Associate Professor Ordu University, School of Physical Education and Sport Department, Ordu, Turkey

* Correspondence

Email: ErhanKara@gmail.com 


\section{Summary}

The importance of balance is considerably high in many sports that require struggle and close contact such as wrestling. Some losses in maintaining the balance due to the movements requiring high intensity during competitions and increase in the risk of injury due to these losses may occur in wrestling athletes. The aim of this study is to Increase the educational level of elite female wrestlers by examining the relationship between Functional Movement Screening Test Scores and static balance performance scores of elite young female wrestlers. 19 elite female wrestlers having average age of $22.94 \pm 2.67$ years, body weight $61.63 \pm 7.25 \mathrm{~kg}$, height $165.37 \pm 5.17 \mathrm{~cm}$ and BMI $22.46 \pm$ $1.60 \mathrm{~kg} / \mathrm{m} 2$ participated in the study. Functional Movement Screen Test TM (FMST ${ }^{\mathrm{TM}}$ ) battery was used in determining the functional movements of the participants, while Tecnobody Prokin 200 Bergamo/Italy was used to determine the total postural stability index values. All static balance measurements were evaluated as standing Double-Leg Eyes Open (DLEO), Eyes Open Single-Leg Dominant Non-Dominant (EOSL-DM and EOSL-ND). Since higher stability index values indicate lower stability, the participants were found to have a negative correlation between non-dominant leg static balance and HS. SM. and TSPU, and between dominant leg static balance and HS. SM. and TSPU. In addition, it was found out that, there was a negative correlation between non-dominant leg static balance, dominant leg static balance and double leg static balance and the FMST ${ }^{\mathrm{TM}}$ scores of the participants. The results of this research can be very effective in improving the educational process in the field of wrestling.

Key words: Wrestling, Functional movement, Static balance, Postural stability, Educational level

\section{Resumen}

La importancia del equilibrio es considerablemente alta en muchos deportes que requieren lucha y contacto cercano, como la lucha libre. Algunas pérdidas en el mantenimiento del equilibrio debido a los movimientos que requieren alta intensidad durante las competiciones y un aumento en el riesgo de lesiones debido a estas pérdidas pueden ocurrir en los atletas de lucha libre. El objetivo de este estudio es aumentar el nivel educativo de las luchadoras de élite examinando la relación entre las puntuaciones de las pruebas de detección de movimiento funcional y las puntuaciones de rendimiento del equilibrio estático de las luchadoras jóvenes de élite. Participaron en el estudio 19 luchadoras de élite con una edad promedio de 22,94 $\pm 2,67$ años, un peso corporal de $61,63 \pm 7,25$ $\mathrm{kg}$, una altura de $165,37 \pm 5,17 \mathrm{~cm}$ y un IMC de $22,46 \pm 1,60 \mathrm{~kg} / \mathrm{m} 2$. La batería Functional Movement Screen Test ${ }^{\mathrm{TM}}$ (FMST ${ }^{\mathrm{TM}}$ ) se utilizó para determinar los movimientos funcionales de los participantes, mientras que Tecnobody Prokin 200 Bergamo / Italia se utilizó para determinar los valores del índice de estabilidad postural total. Todas las medidas de equilibrio estático se evaluaron como ojos abiertos con dos piernas de pie (DLEO), ojos abiertos con una sola pierna, dominante, no dominante (EOSL-DM y EOSL-ND). Dado que los valores más altos del índice de estabilidad indican una estabilidad más baja, se encontró que los participantes tenían una correlación negativa entre el equilibrio estático de la pierna no dominante y la HS. SM. y TSPU, y entre el equilibrio estático de la pierna dominante y HS. SM. y TSPU. Además, se descubrió que había una correlación negativa entre el equilibrio estático de la pierna no dominante, el equilibrio estático de la pierna dominante y el equilibrio estático de las dos piernas y las puntuaciones FMST ${ }^{\text {TM }}$ de los participantes. Los resultados de esta investigación pueden ser muy efectivos para mejorar el proceso educativo en el campo de la lucha libre.

Palabras clave: Lucha, Movimiento funcional, Equilibrio estático, Estabilidad postural, Nivel educacional 


\section{Introduction}

Wrestling is one of the popular sports, but one of the first sports disciplines that was included in the old Olympic Games program in 1896 (Rasoul et al., 2019). However, women's wrestling has increased its popularity internationally since its admission to the 2004 Olympic Games (García Pallarés et al., 2012; Zi-Hong et al., 2013). Elite wrestling includes high-intensity short-interval competitions, training, tactical and technical skills (Zi-Hong et al., 2013). Technical movements are exhibited together with strength, extremity strength and speed during the competition (Ar1 et al., 2020). Thus, an elite wrestler should have a high level of coordination, strength, reaction speed and relative strength. 90. Additionally, strength, endurance, static-dynamic balance and flexibility are extremely vital during competition (Otağ A, Otağ, 2011).

Balance refers to the ability of an individual to maintain the center of gravity in a vertical position on the resting area (Clifton et al., 2013). Upper extremity and core muscles are exposed to high resistance during wrestling competition (Demirkan et a., 2014). Some losses in balance and functional movements and musculoskeletal injuries associated with these losses may occur during the force generation came out (Scudamore, 2017). Functional loss in any part of the skeletalmuscular system causes problems such as weakness, high tonus or pain in another part of the body and affects performance negatively (Wainner et al., 2007). Therefore, postural stability is quite important in many sports branches that require struggle and close contact such as wrestling (MoránNavarro et al., 2015). Moreover, it has also been associated with balance, musculoskeletal injuries and poor postural control (Smith et al., 2013).

Hand interference of opponents during the match may cause a loss of balance. However, wrestlers learn to take advantage of these balance losses over time (Morán-Navarro et al., 2015). This loss that occurs in balance can adversely affect the production of force, as well as causing injuries due to the inability to absorb the force load applied on the muscle (Smith et al., 2013). For this reason, a screening test evaluating more than one part of the body and having validity and reliability is of great importance in the prediction of increased injury risk, movement limitation and asymmetric (right and left) problems in athletes and in preventing injuries. The Functional Movement Screen Test (FMST ${ }^{\mathrm{TM}}$ ), developed by Cook et al., is a test that helps to detect increased injury risk, movement limitation and asymmetry (right and left) problems of athletes (Cook et al., 2006).

An improved balance in wrestling is associated with performance capacity (Alper \& Kolayiş, 2020). The aim of this study is to examine the relationship between functional movement test and static balance performances of elite female wrestlers who have an improved balance feature. The relationship between FMST ${ }^{\mathrm{TM}}$ score and static balance performance scores of elite female wrestlers in the study (hurdle step (HS), shoulder mobilization (SM), trunk stability push- up (TSPU), in-line lunge (ILL), active straight leg raise (ASLR) and double leg static balance, dominant leg static balance, Non-dominant leg static balance) formed sub-hypothesis.

\section{Materials and Method}

19 elite female wrestlers having average age of $22.94 \pm 2.67$ years, body weight $61.63 \pm 7.25 \mathrm{~kg}$, height $165.37 \pm 5.17 \mathrm{~cm}$ and BMI $22.46 \pm 1.60 \mathrm{~kg} / \mathrm{m} 2$ participated in the study. Functional Movement Screen Test TM (FMST ${ }^{\mathrm{TM}}$ ) battery was used in determining the functional movements of the participants, while Tecnobody Prokin 200 Bergamo/Italy was used to determine the total postural stability index values. All static balance measurements were evaluated as standing Double-Leg Eyes Open (DLEO), Eyes Open Single-Leg Dominant Non-Dominant (EOSL-DM and EOSL-ND).

The facts that the participants do not smoke, do not use drug and do not have chronic diseases (diabetes, asthma, chronic obstructive lung disease, hypertension, metabolic syndrome) in the past 
medical history have been determined and they have been included in the study. PARQ test evaluation has been implemented to the research group before the study and ACSM (American College of Sports Medicine) risk factor analysis evaluation has been implemented after the study. Only healthy experimental subjects have been included in the study. All participants were asked not to take part in any sport activities in the last 24 before the test in order to avoid fatigue.

\section{The Functional Movement Screen ${ }^{\mathrm{TM}}$}

No adaptation session was carried out in order to avoid the learning effect of FMST ${ }^{\mathrm{TM}}$ and test kits were introduced only visually. 7 movements in total (deep squat, hurdle step, in-line lunge, shoulder mobility, active straight leg raise, trunk stability push-up and rotary stability pattern) were used in order to evaluate the limitations and asymmetries of motion profiles in the body. FMST ${ }^{\mathrm{TM}}$ each movement was evaluated by a score system between 0 and 3 (Cook, 2010). While " 0 " point was the lowest score within these scores and it was stated that there was a feeling of pain, performing the movement in ideal form and without compensation was evaluated as " 3 " points. The participants were given " 2 " points on the condition that they perform compensation by using different muscle groups during the performance of the movements and " 1 point" was given for loss of balance during the movement. The dominant and non-dominant parts of the body were tested and evaluated separately in order to determine the asymmetries in the movements. The lowest score was recorded in the event that both sides of the body (for movements where both sides were evaluated) had different scores. The maximum FMST ${ }^{\mathrm{TM}}$ total score is 21 . FMST ${ }^{\mathrm{TM}}$ measurements were taken in real time and the participants were allowed to perform three trials for each movement pattern. All FMST $^{\mathrm{TM}}$ measurements were checked and scored by the same person (Cook et al., 2016).

\section{Static Balance Assessment}

Static balance of the participants was determined by measuring the total stability index. All athletes were introduced to the test device (Tecnobody Prokin 200 Bergamo / Italy) and test method one day before the test in order to provide familiarization to the static balance test, and they were allowed to try it once. The participants were asked to look at the opposite screen that was located on the balance platform so that the arms could remain in a fixed position at point " 0 " on the sides by placing their feet naked according to the $\mathrm{x}$-axis and $\mathrm{y}$-axis. The calibration of the balance device was checked before each test. The participants were given verbal feedback during the static balance test. As total stability index values obtained at the end of the test come close to " 0 " degree, it indicates that the static balance is good. If it deviates from " 0 ", it indicates that the static balance gets worse. Balance scores of "0 degrees" were accepted as the maximum balance (Erkılıç \& Şenel, 2019; Rüçhan ET AL., 2018; Topcu \& Arabaci, 2017).

a) Double Leg Static Balance Eyes Open Test: Participants were asked to stand in an upright position with their eyes open for 30 seconds. The data obtained at the end of the test were recorded.

b) Single-Leg Static Balance Eyes Open Test (dominant non-dominant): All participants were randomly asked to stand upright on the dominant (DM) and non-dominant (ND) leg with their eyes open for 30 seconds each. The data obtained at the end of the test were recorded.

\section{Body weight and height measurements}

Measurements were carried out with a metal height scale with a precision of $1 \mathrm{~mm}$., while the participants were in bare feet and in an upright position, and their body weight was measured with bare feet and minimal clothing on the Seca brand electronic scales with a sensitivity of $100 \mathrm{gr}$. (Saaka et al., 2009; Sadeghi \& Mahdavi Nejad, 2019). Body Mass Index (BMI) was calculated with the formula of weight $(\mathrm{kg}) /$ height $\left(\mathrm{m}^{2}\right)$. Descriptive statistics of the participants (age, body weight, height and body mass index (BMI)) were evaluated. TSI balance and FMST TM mean scores and standard deviation were evaluated. Spearman correlation analysis was performed to evaluate the relationship between TSI balance and FMST TM test scores due to their non-parametric distribution. IBM SPSS package program was used in calculating all statistical analysis. 


\section{Results and Disscussion}

Descriptive statistical data of the participants are given in Table 1. The average age of the 19 elite women wrestlers participating in the study was $22.94 \pm 2.67$; average height $165.37 \pm 5.17$; body weight average $61.63 \pm 7.25$; the BMI average has been defined as $22.46 \pm 1.60$. (Table 1.)

Table 1. Descriptive statistics for the physical characteristics of the participants

\begin{tabular}{|c|c|c|c|c|}
\hline Variable & N & Mean \pm SD. & Minimum & Maximum \\
\hline Age $($ year $)$ & 19 & $22.94 \pm 2.67$ & 19 & 29 \\
\hline Body Weight $(\mathrm{kg})$ & 19 & $61.63 \pm 7.25$ & 50 & 80 \\
\hline Height $(\mathrm{cm})$ & 19 & $165.37 \pm 5.17$ & 158 & 180 \\
\hline$*$ BMI $\left(\mathrm{kg} / \mathrm{m}^{2}\right)$ & 19 & $22.46 \pm 1.60$ & 2.03 & 25.16 \\
\hline
\end{tabular}

* Body Mass Index

The scores that 19 elite female wrestlers obtained from the Functional Movement Screen ${ }^{\mathrm{TM}}$ measurement have been given in (Table 2.) FMST ${ }^{\mathrm{TM}}$ total score average of the participants was found to be $18.42 \pm 0.90$. The scores obtained from the deep squat, hurdle step, in-line lunge, shoulder mobility, active straight leg raise, trunk stability push-up, rotary stability movement patterns forming the FMST ${ }^{\mathrm{TM}}$ scores are respectively $2.57 \pm 0.60,2.39 \pm 0.35,2.81 \pm 0.24,2.63 \pm$ $0.36,2.86 \pm 0.22,2.94 \pm 0.22,2.18 \pm 0.24$.

Table 2. Functional movement screen test scores of the participants

\begin{tabular}{|c|c|c|c|c|}
\hline Variable & N & Mean \pm SD. & Minimum & Maximum \\
\hline DS. & 19 & $2.57 \pm 0.60$ & 1 & 3 \\
\hline HS. & 19 & $2.39 \pm 0.35$ & 2 & 3 \\
\hline IIL. & 19 & $2.81 \pm 0.24$ & 2.5 & 3 \\
\hline SM. & 19 & $2.63 \pm 0.36$ & 2 & 3 \\
\hline ASLR. & 19 & $2.86 \pm 0.22$ & 2.5 & 3 \\
\hline TSPU. & 19 & $2.94 \pm 0.22$ & 2 & 2.5 \\
\hline RS. & 19 & $2.18 \pm 0.24$ & 2 & 19.5 \\
\hline Total Score & 19 & $18.42 \pm 0.90$ & 16 & Active \\
\hline
\end{tabular}

$\mathbf{D S}=$ Deep squat, $\mathbf{H S}=$ Hurdle step, $\mathbf{I I L}=$ In-line lunge, $\mathbf{S M}=$ Shoulder mobility, $\mathbf{A S L R}=$ Active straight leg raise, $\mathbf{T S P U}=$ Trunk Stability push-up, $\mathbf{R S}=$ Rotary stability

The scores that 19 elite female wrestlers got from the Total Stability Index measurement are given in (Table 3.) TSI double-leg scores were found as $5.38 \pm 1.11$, TSI dominant leg $5.24 \pm 1.17$ and TSI non-dominant leg scores were determined as $4.71 \pm 1.10$.

Table 3. Total Stability Index scores of the participants

\begin{tabular}{|c|c|c|c|c|}
\hline Variable & $\mathbf{N}$ & Mean \pm SD. & Minimum & Maximum \\
\hline TSI double-leg $\left(^{\circ}\right)$ & 19 & $5.38 \pm 1.11$ & 3.12 & 6.88 \\
\hline TSI Dominat $\left(^{\circ}\right)$ & 19 & $5.24 \pm 1.17$ & 2.59 & 7.02 \\
\hline TSI* Non-dominat $^{\circ}$ ( $)$ & 19 & $4.71 \pm 1.10$ & 2.82 & 6.56 \\
\hline
\end{tabular}

*Total Stability Index

According to the evaluation of the relationship between TSI and FMST TM test scores of the participants, a negative correlation of $-0.360 .-0.135-0.301$ was found in the TSI non-dominant leg and FMST тм hurdle step, shoulder mobility and trunk stability push-up scores, respectively. Negative correlations of $-0.336,-0.055,-0.344$ were found in TSI dominant leg and FMST TM hurdle step, shoulder mobility, and trunk stability push-up scores, respectively. A negative correlation of $0.100,-0.153,-0.172$ was observed in TSI double leg and FMST TM in-line lunge, active straight leg raise, trunk stability push-up scores, respectively (Table 4.) 
Table 4. Statistical Analysis of TSI and FMSTTM Test Score Correlation of the Participants

\begin{tabular}{|c|c|c|c|c|c|c|c|c|}
\hline Variable & $\mathbf{N}$ & DS. & HS. & IIL. & SM. & ASLR. & TSPU. & RS. \\
\hline TSI Double Leg $\left(^{\circ}\right)$ & 19 & 0.063 & -0.012 & -0.100 & 0.051 & -0.153 & -0.172 & 0.086 \\
\hline TSI Dominant Leg $\left(^{\circ}\right)$ & 19 & 0.155 & -0.336 & 0.090 & -0.055 & 0.076 & -0.344 & 0.022 \\
\hline TSI* Non- dominant Leg $\left({ }^{\circ}\right)$ & 19 & 0.055 & -0.360 & 0.100 & -0.135 & 0.109 & -0.301 & 0.043 \\
\hline
\end{tabular}

$\mathrm{P}<0.05 *$ Total Stability Index *, DS = Deep squat, HS = Hurdle step, IIL = In-line lunge, $\mathbf{S M}=$ Shoulder mobility, ASLR = Active straight leg raise, $\mathbf{T S P U}=$ Trunk stability push-up, $\mathbf{R S}=$ Rotary stability

The evaluation of the relationship between the TSI and FMST тм test scores of the participants has been given in (Table 5.) Negative correlation of $-0.016,-0.198,-0.043$ were found between the FMST TM and TSI dominant leg, TSI non-dominant leg and TSI double leg scores of the participants respectively $\mathrm{P}<0.05^{*}$.

Table 5. Statistical Analysis of Spearman Correlation of TSI and FMST TM scores of the participants

\begin{tabular}{|c|c|c|c|c|}
\hline Variable & N & TSI*Dominant Leg $\left({ }^{\circ}\right)$ & $\begin{array}{c}\text { TSI Non-dominant } \\
\text { Leg }\left({ }^{\circ}\right)\end{array}$ & $\begin{array}{c}\text { TSI Double Leg } \\
\left({ }^{\circ}\right)\end{array}$ \\
\hline $\begin{array}{c}\text { FMST TM Total }_{\text {Score }} \\
\text { Score }\end{array}$ & 19 & -0.016 & -0.198 & -0.043 \\
\hline
\end{tabular}

$\mathrm{P}<0.05^{*}$

\section{Discussion}

The primary aim of this study was to examine the relationship between functional movement test scores and static and balance performance of the participants. According to the statistical data of the study, it was observed that there was a negative correlation between FMST TM scores and PSI values of the participants. Although negative correlation is considered to be unfavorable statistically, it actually indicates a positive expected situation because the main reason for this situation can be explained by the fact that the improvement in static balance performance decreases the TSI value. (Erk1lıç \& Şenel, 2019; Rüçhan ET AL., 2018; Topcu \& Arabaci, 2017). Thus, this study shows parallelism with the studies in the literature and explains the negative correlation between the variables in the study. Failure to maintain postural stabilization against different resistance during wrestling competitions may cause deterioration of balance performance. However, wrestlers adapt by learning to cope with this situation over time (Gebel ET AL., 2020). This situation is considered to be important for the wrestlers to maintain continuity of the competition. The cerebral cortex and central nervous system play an important role in maintaining postural control (Rzepko et al., 2019; Yıldırım et al., 2019). In addition, information obtained from the visual, somatosensory and vestibular systems is combined to perform the necessary corrective actions to maintain balance (Azarpaikan \& Torbat, 2018). Wrestling training is effective in providing postural control (Rzepko et al., 2019), lower extremity dynamic balance performance, and increasing exercise capacity (Soyuer \& MIRZA, 2006; Zheng et al.,2019). It is understood that balance performance is extremely effective in winning wrestling competitions (Bulgay \& Polat, 2017; Coskun et al., 2019; Iri et al.,2016).

Balance is a multifaceted task involving the integration of sensory (somatosensory, visual and vestibular), motor and cognitive inputs to perform appropriate neuromuscular activities in order to maintain postural stability (Celenay \& Kaya, 2019; Wikstrom et al., 2009). Neural activity occurs as a result of the neural feedback (NFT) training (Huster \& Herrmann, 2011) by the individual himself. During NFT, individuals can learn to selectively control their brain waves to improve motor function. In addition, NFT has been proven to have positive effects on static and dynamic balance (Azarpaikan \& Torbat, 2018). Additionally, there is a significant relationship between balance performance, leg muscle strength, hamstring, quadriceps ratio and right / left leg balance performance and injury history (Çimen et al., 2018). In addition to this, it should be kept in mind that clinical symptoms such as pain, insomnia, fatigue (Özer, 2019), depression and anxiety, muscle 
weakness, as well as sensory deprivation and cognitive inefficiency may cause balance disorders during balance tests (Celenay \& Kaya, 2019). It is known that there is a relationship between athletes' injury history related to competition or training and identifiable risk factors such as body mass index, body fat ratio, training history, competition and training ground, muscle flexibility, and ligament (Kiesel et al., 2007). it is emphasized that there may be an increase in injury risk under certain score ranges while emphasizing the importance of core stability and mobility requirements for FMST ${ }^{\text {TM }}$ movement patterns (Sadeghi \& Mahdavi Nejad, 2019). Participants in our study have a negative correlation between TSI scores and measurement parameters such as FMST ${ }^{\mathrm{TM}}$ measurement HS, SM, TSPU, IIL and ASLR. Among all these parameters, TSI has the highest negative relationship with the non-dominant leg, HS $r=-0.360$ and TSI dominant leg with TSPU $r=-0.344$. Based on this data, the increase in the static balance performances of elite female wrestlers can provide a small improvement in HS and TSPU functional mobility.

In the study conducted by Bayati et al. (2020), the effect of the 12-week wrestling and warmup protocol on the FMST ${ }^{\mathrm{TM}}$ scores of 24 freestyle wrestlers was investigated, and as a result of the study, a significant increase was observed between the total FMST ${ }^{\mathrm{TM}}$ scores of the experimental group and the TSPU, HS, ILL, and TSPU scores while there was no significant difference in SM, ASLR and RS scores (Özer, 2019). The FMSTTM total scores of athletes with high levels of achievement are significantly higher (39). At the same time, specific thera-band exercises have positive effects on balance (static and dynamic) and FMST TM (Çimen Polat et al.,2018).

\section{Conclusion}

In conclusion, it is thought in this study that improvement in balance performance which is one of the important factors in delivering sportive performance is extremely significant in terms of competition performance according to the information obtained from the literature. it can be mentioned in the light of the findings obtained in this study that there is a relationship between functional movement and postural stabilization in elite female wrestlers.

\section{Conflict of Interest}

The authors declare that they have no conflicts of interest.

\section{References}

Alper, E., Kolayiş İ. E. The relationship between wrestling performance and core stability, dynamic balance, functional movement. CBÜ Beden Eğitimi ve Spor Bilimleri Dergisi, 2020; 15:(1), 48-66.

Arı Y, Tunçel A, Harbili, E. Genç hentbolcularda üst ekstremite kuvveti, anaerobik güç, sürat ve çeviklik arasındaki ilişkiler. Beden Eğitimi ve Spor Bilimleri Dergisi, 2020; 22;(2), 71-81.

Azarpaikan A, Torbat HT. (2018). Effect of somatosensory and neuro feedback training on balance in older healthy adults: a preliminary investigation. Aging clinical and experimental research, 30(7), 745-753

B Huster RJ, Herrmann CS. Neuro feedback training of the upper alpha frequency band in EEG improves cognitive performance. Neuro image, 2011; 54:(2),1427-1431.

Bayati R., Shamsi Majelan A, Mirzaei B, Barbas I. The effect of 12 weeks of wrestling+ warm-up program on functional movement screens cores in cadet wrestlers. Annals of Applied Sport Science, 2019; 7:(1), 39-47

Boguszewski D, Buda, M. Adamczyk JG, Białoszewski D. Relationship between functional limitations of the locomotor system and performance in judo. Polish Journal of Sport and Tourism, 2017; 24;(3), 145 149.

Bulgay C, Polat SÇ. The relationship between the leg power and balance performances on elite wrestlers. Inonu University, journal of Physical Education and Sport Sciences, 2017:4;(3), 59-67.

Celenay ST, Kaya DO. Immediate effects of kinesio taping on pain and postural stability in patients with chronic low back pain. Journal of Bodywork and Movement Therapies, 2019; 23(1), 206-210

Çimen Polat S, Bulgay C, Yarım I, Cicioğlu Hİ, Çetin E. Analysis of the Relationship between Elite Wrestlers' Leg Strength and Balance Performance, and Injury History. Sports, 2018:6;(2), 35. 
Clifton DR, Harrison BC, Hertel J, Hart JM. Relationship between functional assessments and exercise-related changes during static balance. J Strength Cond Res. 2013;27(4):966-72. doi: 10.1519/JSC.0b013e318260b723.

Cook EG, Burton L, Hogenboom B. The use of fundamental movements as an assessment of function-Part 2. North Am J Sports Phys Ther, 2006;(1):32-139.

Cook EG, Burton L, Hogenboom B. The use of fundamental movements as an assessment of function-Part 1. North Am J Sports Phys Ther, 2006;1: 62-72.

Cook G. Movement: Functional movement systems: Screening, assessment and corrective strategies. Nut bourne: Lotus. 2011; ISBN: 978-1-931046-72-5 On Target Publications: Santa Cruz, California, U.S.A.2010 Hard cover, 407pp.

Coskun B, Unlu G, Golshaei B, Kocak S, Kirazcı S. Comparison of the static and dynamic balance between normal-hearing and hearing-impaired wrestlers. Monten. J. Sports Sci. Med. 2019; 8:(1), 11-16 |Doi: 10.26773/mjssm. 190302

Demirkan E, Kutlu M, Koz M, Ozal M, Favre M. Physical Fitness Differences between Freestyle and GrecoRoman Junior Wrestlers. J Hum Kinet. 2014 8(41):245-51. doi: 10.2478/hukin-2014-0052.

Erkılıç A.O., Şenel Ö. Determination of Relationships between Body Composition, Anaerobic Performance and Balance in Wrestlers. International Journal of Sport Culture and Science, 2019; 7:(4), 1-10.

García Pallarés J, López-Gullón JM, Torres-Bonete MD, Izquierdo M. Physical fitness factors to predict female Olympic wrestling performance and sex differences. J Strength Cond Res. 2012;26(3):794803. doi: 10.1519/JSC.0b013e31824741e7.

Gebel A, Lehmann T., Granacher, U. Balance task difficulty affects postural sway and cortical activity in healthy adolescents. Experimental Brain Research, 2020;238:(5).

Iri R., Aktug ZB, Koc M, Sahin I, Murathan F. The effect of fatigue in elite young female wrestlers upon balance performance and reaction, Biomedical Research 2016; 27 (4): 1166-1170.

Kiesel K, Plisky PJ, Voight ML. Can serious injury in professional football be predicted by a preseason functional movement screen? N Am J Sports PhysTher. 2007;2(3):147-158.

Morán-Navarro R., Valverde-Conesa A., López-Gullón J.M., la Cruz-Sánchez D., Pallarés J.G. Can balance skills predict Olympic wrestling performance? Journal of Sport \& Health Research, 2015;7(1).

Okada T, Huxel KC, Nesser TW. Relationship between core stability, functional movement, and performance. The Journal of Strength \& Conditioning Research, 2011;25(1), 252-261.

Otağ A, Otă̆ İ. Cardiac effects of wresting in male children aged 12-14: A study of echocardiography. Cumhuriyet Medical Journal, 2011; 33:(2), 160-163.

Özer Ö. Investigation of the effect of acute muscular fatigue on static and dynamic balance performances in elite wrestlers. Journal of Education and Learning, 2019);8:(5), 179-184.

Rasoul B, Ali MS, Bahman M, Ioannis B. The Effect of 12 Weeks of Wrestling+ Warm-Up Program on Functional Movement Screen Scores in Cadet Wrestlers. Ann Appl Sport Sci 2019;7(1): 39-47. doi: 10.29252/aassjournal.7.1.39

Rüçhan İ. Engin H., Aktuğ Z.B. The effect of 8-week balance training conducted by the wrestlers who are between $12-15$ years on agility and speed performance. Gaziantep University Sport Science Journal,2018; 3(1), 81-90.

Rzepko M, Drozd S, Żegleń P, Król P, Bajorek W, Czarny W. The Effect of Training Experience on Postural Control in Competitive Wrestlers. Journal of Human Kinetics, 2019; 70(1), 39-45

Saaka M, Oosthuizen J, Beatty S. Effect of prenatal zinc supplementation on birthweight. Journal of health, population, and nutrition, 2009;27:(5), 619.

Sadeghi M, Mahdavi Nejad R. The effect of an 8-week selected theraband training on balance and motor performance in young wrestlers, Journal of Sport Biomechanics, 2019;5:(1), 28-37.

Scudamore EM. Functional movement screening and balance under torso-loaded and unloaded conditions Middle Tennessee State University December, 2017.

Smith CA, Chimera NJ, Wright NJ, Warren M. Interrater and intra rater reliability of the functional movement screen. J Strength Cond Res. 2013;27(4):982-987.

Soyuer F, MIRZA M. Relationship between lower extremity muscle strength and balance in multiple sclerosis. Journal of Neurological Sciences, 2006; 23:(4), 257-263

Stanislaw S, Wlodzimierz S. Selected factors influencing the level of general fitness in elite greco-roman wrestlers. Journal of Human Kinetics, 14, 2005;93-104.

Topcu H, Arabaci R. Acute effect of different warm up protocols on athlete's performance. European Journal of Physical Education and Sport Science, 2017; 3:8

Wainner RS, Whitman JM, Cleland JA, Flynn TW. Regional interdependence: a musculoskeletal examination model whose time has come. J Orthop. Sports Phys. Ther. 2007; 37: 658-660.

Wikstrom EA, Naik S, Lodha N, Cauraugh JH. Balance capabilities after lateral ankle trauma and intervention: a meta-analysis. In Database of Abstracts of Reviews of Effects (DARE): Quality-assessed Reviews, 2009. Centre for Reviews and Dissemination (UK).

Yıldırım Y, Arabacı R., Topcu H, Vardar T. The relationship between some physical fitness characteristics and body composition of elite wrestlers.; Int. J. Phys. Ed. Fit. Sports, 2019; 8:1 25-32. 
Zheng P, Dong Y, Wang, M. The Effect of the lower limb balance on the athletic ability of classical wrestlers. Sports Med Rehabil J. 2019; 4 (1), 1045.

Zi-Hong H, Lian-Shi F, Hao-Jie Z, Kui-Yuan X, Feng-Tang C, Da-Lang T, et al. Physiological profile of elite Chinese female wrestlers. J Strength Cond Res. 2013;27:(9):2374-95. doi: 10.1519/JSC.0b013e31827f543c. 